\title{
Advances in Non-Destructive Early Assessment of Fruit Ripeness towards Defining Optimal Time of Harvest and Yield Prediction-A Review
}

\author{
Bo Li ${ }^{\circledR}$, Julien Lecourt and Gerard Bishop * \\ NIAB EMR, East Malling, Kent ME19 6BJ, UK; bo.li@emr.ac.uk (B.L.); Julien.Lecourt@emr.ac.uk (J.L.) \\ * Correspondence: Gerard.bishop@emr.ac.uk; Tel.: +44-(0)1732-843833
}

Received: 7 December 2017; Accepted: 8 January 2018; Published: 10 January 2018

\begin{abstract}
Global food security for the increasing world population not only requires increased sustainable production of food but a significant reduction in pre- and post-harvest waste. The timing of when a fruit is harvested is critical for reducing waste along the supply chain and increasing fruit quality for consumers. The early in-field assessment of fruit ripeness and prediction of the harvest date and yield by non-destructive technologies have the potential to revolutionize farming practices and enable the consumer to eat the tastiest and freshest fruit possible. A variety of non-destructive techniques have been applied to estimate the ripeness or maturity but not all of them are applicable for in situ (field or glasshouse) assessment. This review focuses on the non-destructive methods which are promising for, or have already been applied to, the pre-harvest in-field measurements including colorimetry, visible imaging, spectroscopy and spectroscopic imaging. Machine learning and regression models used in assessing ripeness are also discussed.
\end{abstract}

Keywords: pre-harvest; ripeness; image analysis; machine learning; fruit phenotyping

\section{Introduction}

There are many ways in which the status of global food security can be improved for the world's increasing population. Increased fruit production through adding to the area cropped is not sustainable, thus productivity per unit land area must be increased. Simultaneously there is a need to prevent waste, and for fruit production the timing of harvest is crucial to ensuring that production meets the commercial ripeness specifications. Over- or under-ripe fruits have a lower or even no retail value and represent significant income loss and a waste of resources. For the consumer, too early harvest reduces the taste and quality of fruits whilst a late harvest can lead to reduced shelf life, poor appearance, and "off" flavours and odours. The early in-field assessment of fruit ripeness and the prediction of both harvest date and yield will therefore greatly reduce the waste in the supply chain and thus help towards improving food security.

The non-destructive on-plant assessment of fruit ripeness has received increasing interest as it provides several advantages compared with traditional destructive methods, such as high-throughput assessment, simultaneous multiple measurements and real-time decision making. The phenotypic changes during fruit ripening are complex and in most cases a green hard immature fruit becomes more colourful, softer, sweeter and aromatic. Numerous physical and chemical attributes that can be quantified during ripening include size, shape, texture, firmness, external colour, internal colour, concentration of chlorophyll, soluble solids content (SSC), starch, sugars, acids, oils, and internal ethylene concentration [1]. It is not realistic to simultaneously assess all the quality attributes in the field with non-destructive methods, and destructive laboratory measurements are time-consuming due to the large number of samples required to take account of the within-field variability [2]. Simple representative non-destructive measurements are thus required to assess the ripeness of a fruit. 
The measurement of fruit maturity in a non-destructive manner dates back more than a half century ago with the development of light transmittance techniques [3,4]. Since then, a variety of non-destructive techniques have been introduced including colorimetry [5], visible imaging [6], visible and near infrared (VNIR) spectroscopy [7], hyperspectral imaging [8], multispectral imaging [9], fluorescence imaging [10], acoustic impulse technique [11], Computed Tomography (CT) scan [12], Magnetic resonance imaging (MRI) [13], the acoustical vibration technique [14] and the electronic nose technique [15]. The first six techniques listed above will be considered in this review as they are the most likely to be used in portable devices to enable pre-harvest in-field assessment of fruit ripeness. These techniques have been applied to studies of a large number fruits, and external quality attributes have been measured and correlated with internal characteristics, as shown in Table 1. The non-destructive methods can produce a large amount of data with multiple variables, and thus multivariate analysis is utilized to identify key discriminatory variables that correlate with the ripening status of a fruit [16]. Such key discriminatory variables can be used in regression models, enabling an assessment of fruit quality and thus ripeness.

Currently, the harvest time is mainly estimated by counting of days after flowering, subjective tasting, or visual assessment of fruit colour, texture or plant canopy structure $[17,18]$. All of these methods on their own or in combination are time consuming and not necessarily accurate. The quality attributes or the maturity indices derived from non-destructive techniques can, however, be modelled to predict the optimal time of harvest. Such predictions need to account for changes in environmental conditions and, being a primary factor affecting the rate of plant development [19], air temperature is a key parameter utilized in models predicting optimal harvest time [20]. An example of a typical approach in developing a work flow for predicting an optimal harvest date is given in Figure 1.

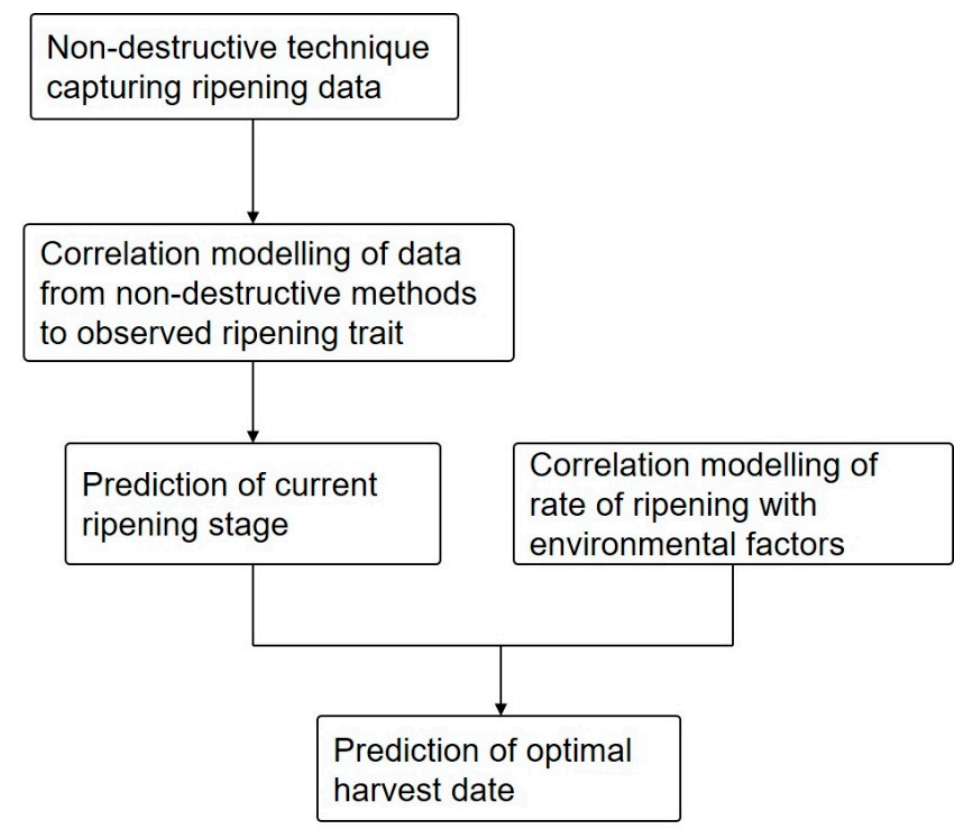

Figure 1. A scheme of the overall workflow for the prediction of the optimal harvest date.

Here we review the non-destructive techniques for the fruit ripeness assessment and the modelling for the prediction of an optimal harvest time. These predictions are based on imaging and/or spectroscopic techniques that quantify the colour and/or spectral qualities of fruits that change due to their molecular composition during the ripening process. 
Table 1. Overview of the non-destructive methods for the assessment of fruit ripening and their correlation with internal characteristics. Abbreviations: SSC (Soluble solid content), DM (Dry matter), MC (Moisture content), TTA (Titratable acidity), TSS (Total soluble solid) and WC (Water content).

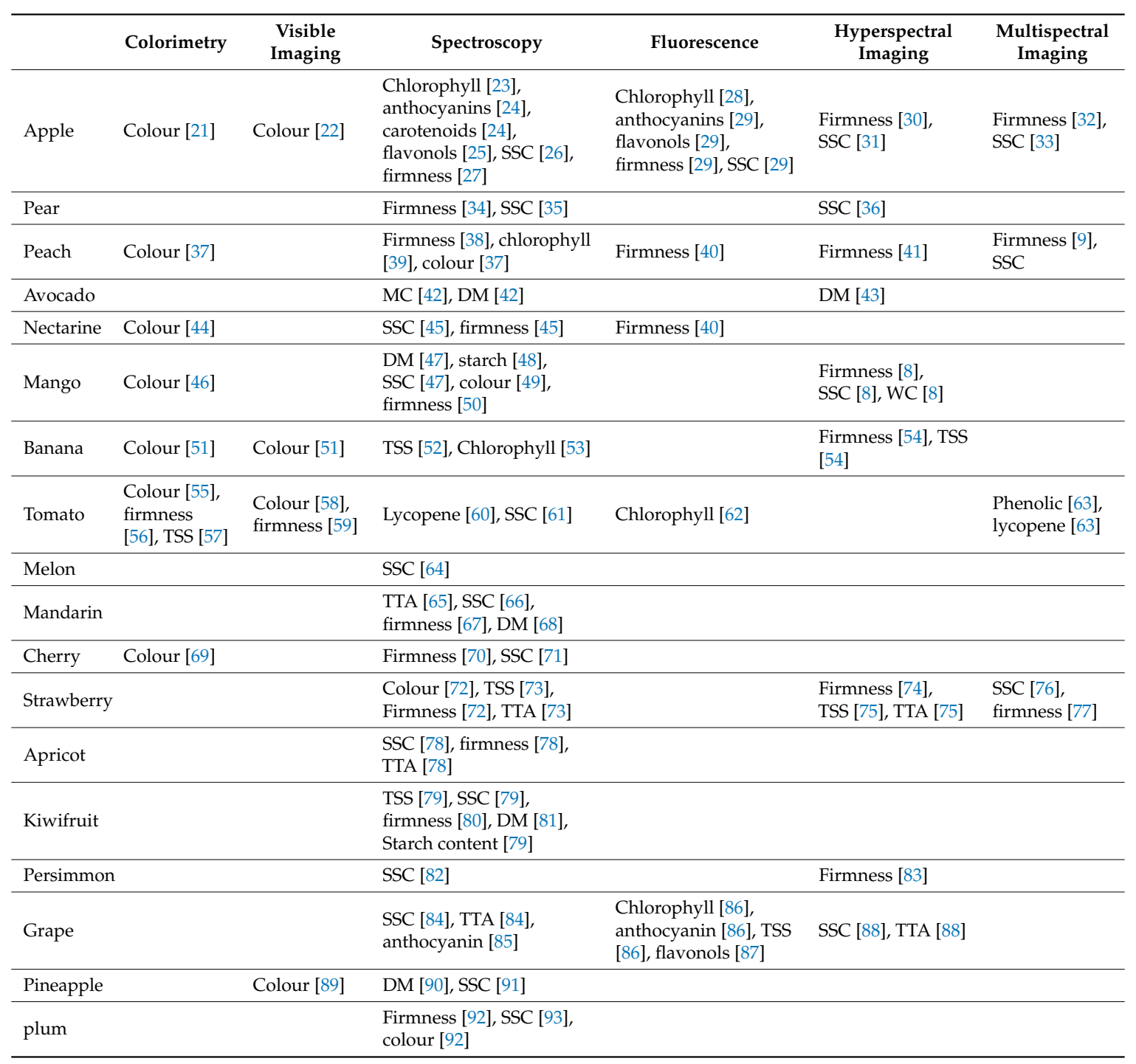

\section{Colour Measurement}

The colour and appearance of a fruit is the initial quality assessment consumers use to judge the acceptability of a fruit. These criteria are related to physical and chemical changes occurring during fruit ripening $[16,94]$. In many fruits, colour change during ripening occurs due to chlorophyll degradation and the increase in the concentration of pigments such as carotenoids or polyphenols [95]. Several fruits have been studied for the relationship between maturity and colour including tomatoes [96], oranges [95], guavas [97], peaches [98], nectarines [44], mangos [46,99], blueberries [100], cherries [100] and pineapples [89]. To measure the changes in fruit colour, the two major methods are the use of colorimeters, and image capture and analysis.

\subsection{Colorimeter}

Colorimeters are traditional non-destructive instruments used extensively in the fruit industry to measure fruit colour [101]. They are more precise than human visual assessment and standardization using CIELAB colour space, which was introduced by Commission Internationale de 1'Eclairage (CIE) in 1976, and provides unified measurements [102]. The three coordinates of CIELAB colour space, $\mathrm{L}^{*}$, 
$a^{*}$ and $b^{*}$, represent the respective values of lightness and the green to red and blue to yellow ratios. CIELAB is close to human perception of colour due to the uniform distribution of colours, and all the colours that can be perceived by human eye can be located on the three coordinates [103]. Several colour indexes have been developed as the indicator of ripeness. In certain experiments only the $\mathrm{a}^{*}$ parameter was correlated with colour change $[97,102,104]$. The $b^{*}$ value has only been reported to be positively correlated with ripeness in peaches [37]. Using more than one of the colour components improves the assessment of ripeness. The ripeness of tomatoes has been assessed using the ratio between $\mathrm{a}^{*}$ and $\mathrm{b}^{*}$, which has shown high positive correlation with lycopene concentration [105-107] and which identifies significant differences for the six USDA ripening classes $[56,101]$. Equations based on $\mathrm{a}^{*}$ and $\mathrm{b}^{*}$ include determining the hue angle and chroma. The hue angle was found to be one of the best parameters to discriminate different ripeness stages for tomatoes, peaches and guavas $[37,97,101,105,107]$. The $L^{*}$ value was also incorporated to the colour models with $a^{*}$ and $b^{*}$ including for citrus [108] and tomatoes [102]. Portable colourimeters are now available commercially [46] and can be carried to the field. However, single fruit measurement is limited in its application to map the ripeness of fruits in the whole field.

Data obtained with colorimeters has been successfully correlated with fruit ripeness by using multivariate analyses. These statistical tests allow the simultaneous model with multiple variables, for example multiple linear regression (MLR) has been used to accurately predict the maturity of mangos using $\mathrm{a}^{*}, \mathrm{~b}^{*}$ and their product as the variables [46]. Other regression methods were also tested in this study, including Partial Least Square (PLS) regression and Principal Component Regression (PCR), but the prediction performance were slightly worse than MLR in the study by Jha et al. [46].

\subsection{Visible Imaging}

Colorimeters are not able to obtain representative colour values due to the limited sampling area compared to the size of the fruit [109]. This limitation can be overcome by 2D colour imaging that converts photons reflected from fruit skin to electrical signals, which are then received by a camera with CCD (Charge-Coupled Device) or CMOS (Complementary Metal Oxide Semiconductor) sensors. Normally, the sensor receives the light and filters it to three channels, which are R (red), G (green) and B (blue), and the intensity values are always determined by fruit samples, illumination and the internal characteristics of the camera [110].

Similar to $L^{*} a^{*} b^{*}$ colour space, it is possible to analyze fruit ripeness in RGB colour space. Schouten et al. showed that the $\mathrm{R}$ component can be used to describe the progressive colour change of tomatoes at different stages of ripeness and that it correlates with changes in fruit firmness [59]. As ripening is a continuously changing process, the exact colour boundaries between different ripeness stages are difficult to determine and if used, arbitrary thresholds for each colour channel need to be provided. Fuzzy logic, a statistical analysis approach reviewed by Yuan and Klir [111], can overcome the need for discrete thresholds and has been applied to the ripeness assessment of mangos and apples [22,112]. Goel et al. used the difference between $\mathrm{R}$ and $\mathrm{B}$ values to enhance the classification of the different tomato ripeness stages, reaching $94.3 \%$ accuracy [113].

Other statistical methods utilized include unsupervised classification, such as K-means and Gustafson-Kessel algorithms, as reviewed in the studies of Hartigan et al. and Lesot et al. respectively $[114,115]$. These have successfully been applied to automatically separate bananas of different ripeness stages based on their RGB values [116]. Rather than only using the average RGB values, the histogram of each channel was used to find matches with predefined reference histograms for each ripeness group [116].

RGB values from images can be transformed to $L^{*} a^{*} b^{*}$ values, and a comparable performance was obtained with a colorimeter for the internal quality assessment of tomato fruits, including Brix and lycopene content [117]. A similar conclusion was drawn from studies in tomatoes [118], cherries [100] and bananas [94]. The RGB values are, however, device dependent and not a perceptually uniform space. Calibration is therefore crucial before the transformation of RGB values into $L^{*} a^{*} b^{*}$ space in 
order to produce parameters comparable with a colorimeter [103]. Statistical modelling approaches including quadratic and neural network models, as described in $[119,120]$, were the best models to convert RGB values into $L^{*} a^{*} b^{*}$ space [110], and Taghadomi et al. adopted the neural network method and obtained a very strong correlation $\left(R^{2}=0.99\right)$ between actual $L^{*} a^{*} b^{*}$ and $R G B$ values in cherries [100].

Other colour space values such as $\mathrm{H}, \mathrm{S}$ and I (for hue, saturation and intensity) and $\mathrm{H}, \mathrm{S}$ and $\mathrm{V}$ (hue, saturation and value), can be derived from RGB values and can better represent human visual perception [89]. Hue is defined as the similarity to the defined colours (red, green, blue and yellow) [121] and saturation is used to describe how colourful a stimulus is relative to its own brightness [122]. Fuzzy logic was successfully applied to group pineapples into three ripeness stages using values derived from $\mathrm{H}, \mathrm{S}$ and I [89]. Ukirade et al. used $\mathrm{H}, \mathrm{S}$ and $\mathrm{V}$ values as the input of the neural network model to classify tomatoes into four ripeness groups [123]. EI-Bendary et al. proposed a more sophisticated method for tomatoes, which used the colour histogram in HSV space and the colour moments (mean, standard deviation and skewness) which measure the colour distribution in an image as the colour features. Principal Component Analysis (PCA) was applied to extract the features for both Linear Discriminant Analysis (LDA) and Support Vector Machine (SVM) models with more than an $80 \%$ Correct Classification Rate (CCR) for five ripening stages [55]. Rather than only using one colour space, colour components from two colour spaces can be combined, such as in the study by Li et al., which used R, B and H from outdoor colour images of blueberries in combination with the K-Nearest Neighbour (KNN), which classifies an object based on a majority vote among its neighbours, [124] to achieve more than an $85 \%$ CCR when separating fruit into four ripening stages [125].

Compared with a colorimeter, colour information can be obtained rapidly from larger area in a 2D image due to the high spatial resolution. The equipment can also be easily attached to moving platform such as tractor, robot or drone for the rapid collection of multiple data collection measurements. There are however challenges that need to be overcome for 2D imaging including the difficulty of segmentation of fruits from the background, device dependent RGB values, and the requirement of homogeneous illumination in the field.

\section{Visible and Infrared Spectroscopy}

When light hits the surface of a fruit it can be absorbed, scattered or re-emitted. The amount of each of these is determined by the physical properties and chemical constituents and thus ripeness of a fruit. Visible and Near InfraRed (VNIR) reflectance spectroscopy measures reflected light between $380 \mathrm{~nm}$ and $2500 \mathrm{~nm}$, which is largely dependent on the light absorption by fruit sample and relates to almost all the major organic compounds. An example of the changes in spectra during ripening is given in Figure 2, which shows marked changes in the values between 400-700 nm and again at longer wavelengths. VNIR spectroscopy has been widely applied as a non-destructive and fast measurement method for multiple quality attributes [126]. More importantly, a portable device has been developed and used in the field [127]. The recorded spectra can be analyzed and related to different ripeness stages by using spectral indices. The whole wavelength scan, or values at key selected wavelengths, are used in regression models to correlate with specific fruit qualities that are associated with fruit ripeness. 


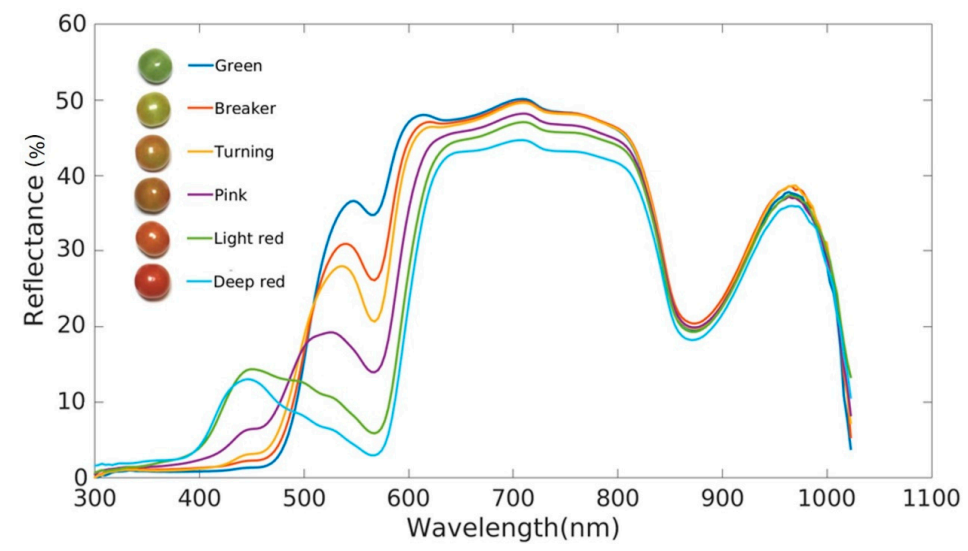

Figure 2. Typical progressive change of reflectance spectra at different ripening stages of tomato.

\subsection{Spectral Indices}

Spectral indices normally combine the surface reflectance at two or more wavelengths in order to indicate the relative abundance of a feature of interest. (It is difficult to use only one wavelength as an index for in-field assessment because the values can be highly affected by the sensor, environmental illumination and particle size [128].) A number of spectral indices have been calculated to describe the progressive change of peel pigment concentration during ripening. Ruiz-Altisent et al. found that the reflectance at $450 \mathrm{~nm}$ and $680 \mathrm{~nm}$ were both associated with peach firmness, but when using the reflectance values from only two wavelengths, the linear correlation factor was low $\left(R^{2}<0.6\right)[129]$. The index of absorption $\left(I_{A D}\right)$ introduced by Ziosi et al. is a robust spectral index obtained by calculating the difference between the absorption at two wavelengths around the chlorophyll-a peak $(670 \mathrm{~nm}$ and $720 \mathrm{~nm})$ [39]. The $I_{A D}$ range was found to be similar across different growing seasons and a good correlation with ripeness was found for peaches [98,130], apricots [131], nectarines [132,133] and plums [92]. Merzlyak et al. identified several spectral indices for the quantification of internal quality attributes of apples related to their ripeness with high correlation $\left(R^{2}>0.8\right)$ [24] and Zude et al. also developed three indices, including the ratio between the transmission at $698 \mathrm{~nm}$ and $760 \mathrm{~nm}$, NDVI and red-edge vegetation stress index (RVSI). Even though all these indices showed good correlations with the colour change of apple peels, the correlation appears to be cultivar dependent and had lower accuracy for the cultivar of 'Jonagold' than "Elstar" [23]. The same phenomenon was also noticed in the study by Shinya et al., where the correlation between firmness and $I_{A D}$ could be extremely different among three cultivars of peaches [98].

\subsection{Full or Selected Wavelengths}

Spectral indices can describe the change of peel pigment concentration during the ripening process and provide comparable values with the colorimetric method [37], but peel colour is not always the only criteria for ripening assessment. The correlation between internal quality attributes related to ripening, such as firmness and SSC, were investigated with full or selected wavelengths from the VNIR spectra.

For the full wavelengths, PLS is the most used regression model to predict fruit quality. The prediction is achieved by extracting a set of orthogonal factors from the predictors, called latent variables, which have the best predictive power [134]. Another common regression model is the Principal Component Regression (PCR), which uses Multiple Linear Regression (MLR) to correlate with the principal components scores extracted from the predictors [135], and which has been applied in some studies for fruit quality assessment $[67,135,136]$. Compared with PLS, PCR showed the drawback that the principal components were obtained without considering the dependent variables.

The variability of physical sample properties and/or the performance of the hardware can result in undesired results including light scattering, path length variations and random noise generated in 
the extracted spectra. These factors reduce the accuracy and robustness of the prediction models [137]. In order to improve the data analysis, a number of studies have applied different pre-processing techniques to the spectra obtained before modelling [136].

Savitzky-Golay (SG) is the most frequently used digital data smoothing filter $[42,49,65,91,138,139]$, which applies the Linear Least Squares method to fit low-degree polynomial data [140]. However, SG has contrasting effects on the performance of multivariate statistical models [141]. For example, Jha et al. compared different pre-processing techniques and found that smoothing did not produce any improvement in comparison with other techniques for the assessment of the firmness in mangos [49]. But Herrera et al. showed that SG filters using a second-order polynomial performed better than other scattering correction methods for the prediction of wine grape Brix [137]. Standard Normal Variate (SNV) $[72,78,142,143]$ and Multiple Scattering Correction (MSC) $[42,67,137,139,144,145]$ are the two most frequently used techniques for scattering correction. MSC is used to eliminate the nonlinear scattering due to the non-uniform travel distance of light by linearizing each spectrum to a reference spectrum, which is the always the mean spectrum [67]. Previous research has shown the similarity between SNV and MSC, for example Ma et al. confirmed that the correlation coefficients were the same when assessing the sugar content of peaches using PLS models with SNV and MSC [146]. SNV can, however, be applied to an individual spectrum without requiring a reference [147]. In some studies, SNV was performed with de-trending, which was used to correct the baseline shift of spectra [72,143].

Generating derivatives of spectra are useful pre-processing techniques to enhance subtle differences and reduce the effect of specular reflection [79,137]. Guo et al. found that the PLS regression model performed better with the first derivative of the spectra than SNV, MSC, and the second derivative for predicting the SSC in strawberries [139]. A similar conclusion was drawn for the Total Soluble Solid (TSS) content prediction of strawberries [73]. The second derivative has also been used in the prediction of chlorophyll content of apples [23], the SSC of kiwifruit, strawberries, cherries, and peaches $[71,79,148,149]$, and the firmness of apricots [78]. Carlini et al. compared the second derivative, MSC and SNV methods, and found that the second derivative showed the best performance for the prediction of SSC in cherries [71]. Interestingly, pre-processing techniques are not always beneficial to the spectral analysis. Clément et al. applied all the above-mentioned pre-processing techniques to the prediction of tomato ripeness, but it was found that none of them showed improvements on a PLS model due to the low levels of noise [61]. Likewise, Jaiswal et al. also found that the best predictions of TSS and DM (Dry Matter) content of bananas with PLS model was obtained with no pre-processing to the spectra [52].

In some studies, only a small number of selected wavelengths were used to reduce the multicollinearity among variables and to be modelled by the Multiple Linear Regression (MLR) model. The key wavelengths can be identified manually or automatically. The manual selection of key wavelengths has been used for the prediction of Brix in mangos [150] and SSC for grapes, limes and star fruit [84]. Guthrie et al. calculated the correlation coefficients between the second derivative of spectra and Brix values as the criteria of wavelength selection for the MLR model. This method provided better predictions than when using the first derivative [90] and had previously been used in the prediction peach Brix levels [151].

Automated wavelength selection methods, such as stepwise wavelength selection, have also been used to aid the predictive power of models. The first wavelength selected is that with the highest correlation to the depended variable. Additional wavelengths are added, one by one, in order to strengthen the correlation until none of the remaining wavelengths are significant. This method was used for the SSC prediction of peaches [152], melons and pineapples [153]. The Genetic Algorithm (GA), which uses natural selection and random mutations based on prediction accuracy, is another efficient automated method for identifying key wavelengths and was successfully applied to the SSC prediction of apples [154].

A comparison of the performance of PLS and MLR for the assessment of the maturity of mangos indicated that when using MLR, a poorer correlation of data was observed and led to overfitting, 
as seen by the large gap between the correlation coefficients of calibration and validation models [155]. A similar phenomenon was also observed for the prediction of TSS and DM for bananas [52]. However, if the key wavelengths that were selected represented most of the variance of the whole spectra but low collinearity, MLR can show better performance than PLS, such as in the firmness prediction of mangos [50]. These two methods of modelling were also compared for the prediction of Brix values in mangos and, interestingly, both correlation coefficients were high and comparable [150]. Consequently, it is unclear which model can provide a better prediction, as the performance of MLR is largely dependent on the wavelength selection.

The correlation has always been higher for the prediction of SSC than of the firmness of fruit by using spectroscopic methods. Park et al. showed that the prediction of firmness was more complicated than SSC as it was not determined by a single analyte or a limited group of related chemicals [156]. For both SSC and firmness prediction, the performance of the model is always cultivar dependent, and the calibration model trained by using mixed cultivars produces a lower correlation than when using results from an individual cultivar. A limited number of studies were focused on the assessment in-field, but compared with indoor measurement, the prediction is less accurate $[27,45,48]$.

Spectroscopic methods utilize longer wavelengths than colorimeter and visible imaging, but similar to colorimeter, they are not likely to be applied as high-throughput ripening assessment tools due to the low spatial resolution. The accuracy of the internal quality measurement is influenced by sample temperature, which needs to be compensated for by an extra calibration model [48]. Spectroscopy has been used in assessing the quality of a large variety of fruits, and portable commercial spectrometers have been developed [48,78,127,157], but most of the studies have focused on the indoor, post-harvest assessment of fruit maturity. Inconsistent performances were observed for the models developed by spectra taken indoor and on-tree. Predicting apple firmness and SSC both on the tree and during storage showed that the on-tree PLS model had the best correlation coefficients for both firmness and SSC $[27,158]$. However, for nectarines, the on-tree model performed worse than the post-harvest one [45]. Consequently, for the on-tree ripeness assessment, it is necessary to build the prediction model with spectra taken in-field and understand the effect of environmental factors on the quality of spectra.

\section{Fluorescence Sensor}

Fruit degreening (i.e., the loss of chlorophyll) is an effective indicator of fruit ripening, and thus measuring chlorophyll content using a fluorimetric sensor can be correlated to fruit ripeness traits [40].

One chlorophyll fluorimetric method measures the photochemical and non-photochemical processes with the illumination of actinic light [159]. A Pulse-Amplitude-Modulation (PAM) based fluorometer has been developed commercially, which uses visible light at the blue region as the excitation and measures the minimum $\left(F_{0}\right)$ and maximum $\left(F_{m}\right)$ emitted fluorescence. The maximum quantum yield $\left(F_{m}-F_{0}\right) / F_{m}$ was calculated and this parameter was found to be negatively correlated with the ripening stage of apples [160] and papaya fruit [161]. This chlorophyll fluorimetric method is popular in the laboratory, but difficult to apply in-field as the samples need to be dark-adapted. For example, the papaya samples in the study of Urbano et al. were dark-adapted for $30 \mathrm{~min}$ with a dark towel [161]. Bodria et al. designed a fluorescence imaging system which measured the light emission at $690-740 \mathrm{~nm}$ with the excitation light in UV-blue and red regions, and a good correlation was achieved between the quality parameters, including firmness and SSC of fresh apples, and detected fluorescence, even though the hue value of the skin colour showed little change. However, the correlation was lower for peaches and nectarines [40]. The fruit samples measured by this fluorescence imaging system were not dark adapted, but the equipment has only been designed for the laboratory use.

In order to reduce the influence of environmental factors on the absolute fluorescence intensity at a single band, which limits in-field application [162], more studies were focused on the understanding of the fluorescence ratios using various light sources of defined wavelengths. This has led to the development 
of a handheld, multi-parametric fluorescence sensor: Multiplex ${ }^{\circledR}$ (Force-A, Orsay, France), with four LED light sources and three synchronized fluorescence detectors [10]. The most common informative indices utilized fluorescence from anthocyanins (ANTH), flavonols (FLAV), and chlorophyll (CHL) to indicate fruit ripeness. In the study of Betemps et al., CHL showed a positive correlation with the firmness of apples and the authors also obtained a good negative correlation between FR_RED and SSC [29]. The in-field assessment of CHL was also successfully applied to grapes, with a high correlation with TSS, and the combination of CHL and ANTH can be used as a robust decision tool to predict harvest time [86]. For tomatoes, all the indices were found to correlate well with the time-shift in the tomato ripening process in the study of Hoffmann et al. [62]. The blue to red fluorescence ratio (B_UV/RF_UV) was measured as an effective parameter for the assessment of the ripeness of oil palm with rough skin, and when combined with the Classification and Regression Tree (C\&RT) method resulted in an overall correct classification rate of 90\% for three different ripeness stages [163]. Current studies of fluorescence sensors are focused only on the analysis of specific parts of a fruit, which limits their potential use for high throughput measurements in the field.

\section{Spectral Imaging}

\subsection{Hyperspectral Imaging (HSI)}

Hyperspectral imaging (HSI) has emerged as a powerful tool for the inspection of fruit quality. HSI generates a three-dimension imaging cube with images at a range of continuous wavelengths. A single spectrum can be extracted from each individual pixel representing the absorption properties and the textural information of fruit samples [164]. Similar with traditional visible imaging and spectroscopic methods, HSI is non-destructive and requires little sample preparation, but it is advantageous in that it can record both spatial and spectral information simultaneously [165]. For the assessment of fruit quality, two types of wavelength dispersion devices are normally used i.e., line scanning and area scanning coupled with an imaging sensor for the HSI image acquisition. A line scanning device has the imaging spectrograph dispersing the incident light into different wavelengths instantaneously between the visible and the near infrared wavelength range (380-1700 nm). Line scanning HSI cameras scan the samples continuously in one direction, so they can be attached to moving platforms such as tractors [166], robots [167] and unmanned aerial vehicles (UAV) [168].

The hyperspectral image can be handled in two different ways (1) light scattering analysis and (2) spectral analysis. Modified Lorentzian Distribution (MLD), which correlates the data obtained with a predefined distribution curve by using a distribution function, can be used to describe the scattering profile and the fitting parameters that were used as the variables for the stepwise MLR model [30]. The results of this study suggest that spectral scattering from all wavelengths or selected wavelengths can provide more accurate predictions of apple firmness than using the secondary properties such as spectral absorption [30]. Similar methods were also employed for the prediction of peach firmness, but with MLR models, different results were obtained when using two different cultivars [41]. Mendoza et al. combined both the spectral and image analysis techniques on scattering images, including discrete and continuous wavelet transformation decomposition, first order statistics, Fourier analysis, co-occurrence matrix, and Variogram analysis, but little improvement on the prediction of firmness and SSC of apples was found, with the performance of the PLS model being cultivar dependent [31]. Wang et al. used two different feature selection methods which were Uninformative Variable Elimination (UVE) [169] and Supervised Affinity Propagation (SAP) [170]. The output of two PLS models with two feature selection methods were combined as the input into an Artificial Neural Network (ANN) model that gave a correlation coefficient of 0.83 [171]. The scattering profile was also used for the prediction of firmness of peaches [41].

The average spectra of the region of interest (ROI) have also been modelled for the assessment of fruit quality. The average spectra from whole wavelength scan (400-1000 nm) were used with a PLS model to predict the SSC of grapes. The correlation coefficients were similar for both white and 
red grapes [88]. The same method has also been used to predict the TSS of strawberries [75], and the firmness and SSC of blueberries [172]. Key wavelengths have also been selected, with different feature selection techniques, before modelling in order to reduce the redundancy of the whole spectral dataset. One of widely used feature selection criteria is based on beta coefficients derived from PLS models. The PLS models measured how great effect an independent variable has on the dependent variable. A comparison of the performance of different MLR models with wavelength selection based on beta coefficients and PLS models with full spectra as input, showed that the final outcomes were similar for the internal quality measurement of strawberries [75]. The same feature selection methods were also used by Rajkumar et al. to predict the firmness and TSS of bananas by MLR model, and a good correlation was achieved for both quality attributes with correlation coefficients of 0.91 and 0.85 , respectively [54]. Another key wavelength selection method which can solve the collinearity problem is the Successive Projection Algorithm (SPA), which iteratively adds wavelengths one by one until a specific number of wavelengths is achieved with a minimum redundant information content [173]. This method has been used to select the feature wavelengths for input to the PLS model and a high correlation $\left(\mathrm{R}^{2}=0.92\right)$ was found for predicting persimmon firmness [83].

Overall HSI is a promising technique for fruit ripeness assessment. In-field application of this technique will need to overcome the challenges of handling the large data output and the calibration of variable light levels whilst in the crop.

\subsection{Multispectral Imaging (MSI)}

Multispectral imaging is a form of HSI that collects data at specific wavelengths instead of scanning the whole wavelength range. This can be accomplished using a frame scanning imaging system with Liquid Crystal Tunable Filter (LCTF) coupled with CCD or CMOS sensor. Lu et al. used five wavelengths, based on previous studies, to correlate their scattering profiles with the firmness and SSC of apples using an ANN model. They obtained a reasonably high correlation for both quality attributes, which were $R^{2}=0.87$ and 0.77 , respectively [174]. Another lower-cost MSI system uses a rotating filter wheel containing a few bandpass filters instead of LCTF, but the tuning speed is lower than LCTF. This device has been used to predict the firmness and SSC of peaches with the best combination of four wavelengths, and high correlation coefficients were achieved; 0.94 and 0.97, respectively [76]. The prediction of firmness was higher than the prediction by HSI [41]. Similarly, Liu et al. used MSI with 19 wavelengths to predict the firmness and TSS of strawberries. PLS, SVM and ANN were compared with the best correlation coefficients of 0.94 and 0.83 , respectively [74], which were comparable with HSI for prediction of TSS of strawberries [75].

Among the techniques described above, MSI is the most promising for in-field measurement as it can record high resolution images at selected key wavelengths for the prediction of specific quality attributes. Compared with HSI, MSI can be lower cost and easier to convert into portable devices, and the output imaging dataset will be smaller. A portable MSI device with four narrow-band light sources and four reflectance sensors of different wavelengths at 570, 670, 750 and $870 \mathrm{~nm}$ has been developed [130]. This device was used to classify oil palm into different stages of ripeness using quadratic discriminant analysis and discriminant analysis with Mahalanobis distance classifiers with a correct classification rate of $>85 \%$ being achieved [175].

\section{Prediction of Optimal Harvest Date}

Non-destructive methods are very promising for the ripeness assessment in-field, but the most critical question is to how to link such assessment to predict yield and the optimal harvest date [18]. This is highly challenging and made complicated by ripeness variability within and between plants.

Yang et al. recorded the HSI spectra of tomatoes at different growing stages, and the PLS model was applied to predict the growing stage with the best correlation coefficient being 0.89 . It was also found that the key wavelengths were in the visible and infrared regions (400-2100 nm) [176]. A Similar method was employed to predict the number of days until the commercial harvest of 
apples. The calibration model was built with eight cultivars and a good correlation $\left(R^{2}=0.93\right)$ was found for the spectral range between $380 \mathrm{~nm}$ and $2000 \mathrm{~nm}$ [177]. Environmental factors such as temperature, light levels, humidity, etc. significantly influence the development of crop fruit, and it is essential to incorporate important environmental factor predictions for the determination of the optimal harvest date [178]. Several crop models have been developed since the 1960s by Loomis et al. [179] with the input of environmental factors both for in-field and greenhouse prediction. Such models are difficult to use due to the number of input variables [180-185]. Qiu et al. investigated the dominant environmental factors in greenhouses for tomato growth and it was found that temperature, humidity and Photosynthesis Active Radiation (PAR) show a positive or negative correlation to crop growth [185]. The influence of temperature has also been reported in a number studies such as for tomatoes [178], grapes [186], apples [187], mangos [188], blueberries [18], apricots [189] and strawberries [190]. Shewfelt et al. studied the colour change at different constant temperatures, but the variation of the temperature within each day was not considered [96]. Muñoz et al. developed a time series regression model for the prediction of the harvest date of blueberries, and the minimum and maximum of daily temperatures from the weather forecast for two weeks ahead were used as input for the model [18]. This method was closer to a real application and potentially could be applied with non-destructive techniques which could determine the current ripening stage. Environmental temperature affects the fruit growth, and it was also found that the fruit temperature also influenced the near infrared reflectance spectrum in a non-linear way [146]. Kawano et al. compensated for the surface temperature effect by developing a combined MLR model, which covered a variation of temperatures ranging between 21 and $31{ }^{\circ} \mathrm{C}$ [191]. Peirs et al. compared a global calibration model that covers a wide temperature range and calibration models for each temperature range. Both methods performed well for the SSC prediction of apples, but for the practical purpose, the global calibration model was preferred [26].

\section{Conclusions}

Although now slighted outdated, the key study by the Food and Agricultural Organisation (FAO) indicated that global food waste and losses in 2009 was estimated to be one-third (by weight) of all food produced in the world [192]. The prevention of such losses and waste is therefore a major driver to improve global food security. Here we have reviewed a range of non-destructive techniques and the data modelling methods for the assessment of fruit ripening and the prediction of the optimal harvest date. Knowing when to pick will not only depend on the fruit-to ensure the optimal taste, quality and postharvest performance-but also on the local circumstances including weather, the supply chain and markets. Having an affordable, portable device to inform this decision is crucial and the non-destructive techniques discussed above have all been developed into such devices, which will help to reduce waste.

Such devices include colorimeters that can record accurate colour information, but only for individual fruit. 2D imaging overcomes this limit as it images larger areas and can be fitted on a moving platform. However, 2D imaging can only obtain colour information, which is not adequate as an indicator of ripeness for all fruits. Similar to colorimeter and 2D imaging, fluorescence detects the colour change, especially the change of content of chlorophyll. Spectroscopy in visible and NIR regions correlates with both colour and internal quality attributes, which can provide a better prediction of fruit ripeness. Hyperspectral imaging has the advantage of both spectroscopy and 2D imaging, and can be integrated with a moving platform. However, due to the high expense and large dataset generation, it is still mainly used in the lab. Multispectral imaging has the potential to overcome the limitation of hyperspectral imaging but the reliability of the measurement in-field needs to be further investigated. Miniaturization and computational capacity will be major technical hurdles for ensuring that the devices can be used in the field and provide a real-time assessment of fruit quality and ripeness. Simultaneous to the development of the hardware needed for the data modelling 
techniques is important so that these solutions can utilize not only data from the controlled laboratory conditions, but also from the more challenging field conditions with a changeable environment.

Acknowledgments: Gerard Bishop acknowledges support from Biotechnology and Biological Sciences Research Council (BBSRC) grant ref BB/P004881/1.

Author Contributions: Bo Li is the key author, who reviewed previous literature and wrote the manuscript; Julien Lecourt supervised the work, provided ideas and contributed to writing; Gerard Bishop proposed the topic, supervised the work, and contributed to writing and editing the manuscript before submission.

Conflicts of Interest: The authors declare no conflict of interest.

\section{References}

1. Reid, M.S. Maturation and Maturity Indices. Postharvest Technol. Hortic. Crops 2009, 3, 55-62.

2. Vanoli, M.; Buccheri, M. Overview of the methods for assessing harvest maturity. Stewart Postharvest Rev. 2012, 8, 1-6. [CrossRef]

3. Birth, G.S.; Norris, K.H. An instrument using light transmittance for nondestructive measurement of fruit maturity. Food Technol. 1958, 12, 592-595.

4. Ernest, J.V.; Birth, G.A.; Sidwell, A.P.; Golumbic, C. Evaluation of light transmittance techniques for maturity measurements of the purple plum (Italian prune). Food Technol. 1958, 12, 42.

5. Baltazar, A.; Aranda, J.I.; González-Aguilar, G. Bayesian classification of ripening stages of tomato fruit using acoustic impact and colorimeter sensor data. Comput. Electron. Agric. 2008, 60, 113-121. [CrossRef]

6. Choi, K.; Lee, G.; Han, Y.J.; Bunn, J.M. Tomato maturity evaluation using color image analysis. Trans. ASAE 1995, 38, 171-176. [CrossRef]

7. Yang, H.Q. Nondestructive Prediction of Optimal Harvest Time of Cherry Tomatoes Using VIS-NIR Spectroscopy and PLSR Calibration. Adv. Eng. Forum 2011, 1, 92-96. [CrossRef]

8. Sivakumar, S.S.; Qiao, J.; Wang, N.; Gariépy, Y.; Raghavan, G.S.V.; McGill, J. Detecting maturity parameters of mango using hyperspectral imaging technique. In Proceedings of the 2006 ASAE Annual Meeting, Portland, OR, USA, 9-12 July 2006.

9. Lleó, L.; Barreiro, P.; Ruiz-Altisent, M.; Herrero, A. Multispectral images of peach related to firmness and maturity at harvest. J. Food Eng. 2009, 93, 229-235. [CrossRef]

10. Cerovic, Z.G.; Goutouly, J.; Hilbert, G.; Destrac-Irvine, A.; Martinon, V.; Moise, N. Mapping winegrape quality attributes using portable fluorescence-based sensors Zoran. Frutic 2009, 9, 301-310. [CrossRef]

11. Stone, M.L.; Armstrong, P.R.; Zhang, X.; Brusewitz, G.H.; Chen, D.D. Watermelon maturity determination in the field using acoustic impulse impedance techniques. Trans. ASAE 1996, 39, 2325-2330. [CrossRef]

12. Kotwaliwale, N. Monitoring of mango (Mangifera indica L.) (Cv.: Chousa) ripening using X-ray computed tomography. In Proceedings of the 2012 Sixth International Conference on Sensing Technology (ICST), Kolkata, India, 18-21 December 2012.

13. Zhang, L.; McCarthy, M.J. Measurement and evaluation of tomato maturity using magnetic resonance imaging. Postharvest Biol. Technol. 2012, 67, 37-43. [CrossRef]

14. Taniwaki, M.; Hanada, T.; Tohro, M.; Sakurai, N. Non-destructive determination of the optimum eating ripeness of pears and their texture measurements using acoustical vibration techniques. Postharvest Biol. Technol. 2009, 51, 305-310. [CrossRef]

15. Brezmes, J.; Fructuoso, M.L.L.; Llobet, E.; Vilanova, X.; Recasens, I.; Orts, J.; Saiz, G.; Correig, X. Evaluation of an electronic nose to assess fruit ripeness. IEEE Sens. J. 2005, 5, 97-108. [CrossRef]

16. Wu, D.; Sun, D.-W. Advanced applications of hyperspectral imaging technology for food quality and safety analysis and assessment: A review-Part I: Fundamentals. Innov. Food Sci. Emerg. Technol. 2013, 19, 1-14. [CrossRef]

17. François, I.M.; Mariën, E.; Brijs, K.; Coppin, P.; De Proft, M. The use of Vis/NIR spectroscopy to predict the optimal root harvesting date of chicory (Cichorium intybus L.). Postharvest Biol. Technol. 2009, 53, 77-83. [CrossRef]

18. Muñoz, C.; Ávila, J.; Salvo, S.; Huircán, J.I. Prediction of harvest start date in highbush blueberry using time series regression models with correlated errors. Sci. Hortic. 2012, 138, 165-170. [CrossRef] 
19. Hatfield, J.L.; Prueger, J.H. Temperature extremes: Effect on plant growth and development. Weather Clim. Extremes 2015, 10, 4-10. [CrossRef]

20. Adams, S.R.; Cockshull, K.E.; Cave, C.R.J. Effect of temperature on the growth and development of tomato fruits. Ann. Bot. 2001, 88, 869-877. [CrossRef]

21. Ferre, G.; Massol, G.; Le Fur, G.; Villeneuve, F. Apple Colour and Ripeness. Use of a Colorimeter: Prospects; Infos CTIFL: Paris, France, 1987.

22. Dadwal, M.; Banga, V.K. Estimate ripeness level of fruits using RGB color space and fuzzy logic technique. Int. J. Eng. Adv. Technol. 2012, 2, 225-229.

23. Zude, M. Comparison of indices and multivariate models to non-destructively predict the fruit chlorophyll by means of visible spectrometry in apple fruit. Anal. Chim. Acta 2003, 481, 119-126. [CrossRef]

24. Merzlyak, M.N.; Solovchenko, A.E.; Gitelson, A.A. Reflectance spectral features and non-destructive estimation of chlorophyll, carotenoid and anthocyanin content in apple fruit. Postharvest Biol. Technol. 2003, 27, 197-211. [CrossRef]

25. Solovchenko, A.E.; Chivkunova, O.B.; Gitelson, A.A.; Merzlyak, M.N. Non-destructive estimation pigment content, ripening, quality and damage in apple fruit with spectral reflectance in the visible range. Fresh Prod. 2010, 4, 91-102.

26. Peirs, A.; Scheerlinck, N.; Nicola1, B.M. Temperature compensation for near infrared reflectance measurement of apple fruit soluble solids contents. Postharvest Biol. Technol. 2003, 30, 233-248. [CrossRef]

27. Zude, M.; Herold, B.; Roger, J.M.; Bellon-Maurel, V.; Landahl, S. Non-destructive tests on the prediction of apple fruit flesh firmness and soluble solids content on tree and in shelf life. J. Food Eng. 2006, 77, 254-260. [CrossRef]

28. Zude-Sasse, M.; Truppel, I.; Herold, B. An approach to non-destructive apple fruit chlorophyll determination. Postharvest Biol. Technol. 2002, 25, 123-133. [CrossRef]

29. Betemps, D.L.; Fachinello, J.C.; Galarça, S.P.; Portela, N.M.; Remorini, D.; Massai, R.; Agati, G. Non-destructive evaluation of ripening and quality traits in apples using a multiparametric fluorescence sensor. J. Sci. Food Agric. 2012, 92, 1855-1864. [CrossRef] [PubMed]

30. Peng, Y.; Lu, R. Analysis of spatially resolved hyperspectral scattering images for assessing apple fruit firmness and soluble solids content. Postharvest Biol. Technol. 2008, 48, 52-62. [CrossRef]

31. Mendoza, F.; Lu, R.; Ariana, D.; Cen, H.; Bailey, B. Integrated spectral and image analysis of hyperspectral scattering data for prediction of apple fruit firmness and soluble solids content. Postharvest Biol. Technol. 2011, 62, 149-160. [CrossRef]

32. Peng, Y.; Lu, R. An LCTF-based multispectral imaging system for estimation of apple fruit firmness: Part II. Selection of optimal wavelengths and development of prediction models. Trans. ASABE 2006, 49, 269-275. [CrossRef]

33. Peng, Y.; Lu, R. Prediction of apple fruit firmness and soluble solids content using characteristics of multispectral scattering images. J. Food Eng. 2007, 82, 142-152. [CrossRef]

34. Cavaco, A.M.; Pinto, P.; Antunes, M.D.; Silva, J.M.; da Guerra, R. "Rocha" pear firmness predicted by a Vis/NIR segmented model. Postharvest Biol. Technol. 2009, 51, 311-319. [CrossRef]

35. Shao, Y.; Bao, Y.; He, Y. Visible/Near-Infrared spectra for linear and nonlinear calibrations: A case to predict soluble solids contents and $\mathrm{pH}$ value in peach. Food Bioprocess Technol. 2011, 4, 1376-1383. [CrossRef]

36. Tiansheng, H.; Jun, Q.; Wang, N.; Ngadi, M.O.; Zuoxi, Z.; Zhen, L. Non-destructive inspection of Chinese pear quality based on hyperspectral imaging technique. Trans. Chin. Soc. Agric. Eng. 2007, 2, 29.

37. Ferrer, A.; Remon, S.; Negueruela, A.I.; Oria, R. Changes during the ripening of the very late season Spanish peach cultivar Calanda: Feasibility of using CIELAB coordinates as maturity indices. Sci. Hortic. 2005, 105, 435-446. [CrossRef]

38. Lafuente, V.; Herrera, L.J.; Pérez, M.D.M.; Val, J.; Negueruela, I. Firmness prediction in Prunus persica 'Calrico'peaches by visible/short-wave near infrared spectroscopy and acoustic measurements using optimised linear and non-linear chemometric models. J. Sci. Food Agric. 2015, 95, 2033-2040. [CrossRef] [PubMed]

39. Ziosi, V.; Noferini, M.; Fiori, G.; Tadiello, A.; Trainotti, L.; Casadoro, G.; Costa, G. A new index based on vis spectroscopy to characterize the progression of ripening in peach fruit. Postharvest Biol. Technol. 2008, 49, 319-329. [CrossRef] 
40. Bodria, L.; Fiala, M.; Guidetti, R.; Oberti, R. Optical techniques to estimate the ripeness of red-pigmented fruits. Trans. ASAE 2004, 47, 815-820. [CrossRef]

41. Lu, R.; Peng, Y. Hyperspectral Scattering for assessing Peach Fruit Firmness. Biosyst. Eng. 2006, 93, 161-171. [CrossRef]

42. Olarewaju, O.O.; Bertling, I.; Magwaza, L.S. Non-destructive evaluation of avocado fruit maturity using near infrared spectroscopy and PLS regression models. Sci. Hortic. 2016, 199, 229-236. [CrossRef]

43. Girod, D.; Landry, J.A.; Doyon, G.; Osuna-García, J.A.; Salazar-García, S.; Goenaga-Portela, R. Evaluating Hass avocado maturity using hyperspectral imaging. Caribb. Food Crops Soc. Proc. 2008, 44, 144-154.

44. Luchsinger, L.E.; Walsh, C.S. Development of an objective and non-destructive harvest maturity index for peaches and nectarines. Acta Hortic. 1998, 465, 679-688. [CrossRef]

45. Pérez-Marín, D.; Sánchez, M.T.; Paz, P.; Soriano, M.A.; Guerrero, J.E.; Garrido-Varo, A. Non-destructive determination of quality parameters in nectarines during on-tree ripening and postharvest storage. Postharvest Biol. Technol. 2009, 52, 180-188. [CrossRef]

46. Jha, S.N.; Chopra, S.; Kingsly, A.R.P. Modeling of color values for nondestructive evaluation of maturity of mango. J. Food Eng. 2007, 78, 22-26. [CrossRef]

47. Subedi, P.; Walsh, K.; Purdy, P. Determination of optimum maturity stages of mangoes using fruit spectral signatures. Int. Soc. Hortic. Sci. 2010. [CrossRef]

48. Saranwong, S.; Sornsrivichai, J.; Kawano, S. On-tree evaluation of harvesting quality of mango fruit using a hand-held NIR instrument. J. Near Infrared Spectrosc. 2003, 11, 283-293. [CrossRef]

49. Jha, S.N.; Kingsly, A.R.P.; Chopra, S. Non-destructive determination of firmness and yellowness of mango during growth and storage using visual spectroscopy. Biosyst. Eng. 2006, 94, 397-402. [CrossRef]

50. Schmilovitch, Z.; Mizrach, A.; Hoffman, A.; Egozi, H.; Fuchs, Y. Determination of mango physiological indices by near-infrared spectrometry. Postharvest Biol. Technol. 2000, 19, 245-252. [CrossRef]

51. Mendoza, F.; Dejmek, P.; Aguilera, J.M. Calibrated color measurements of agricultural foods using image analysis. Postharvest Biol. Technol. 2006, 41, 285-295. [CrossRef]

52. Jaiswal, P.; Jha, S.N.; Bharadwaj, R. Non-destructive prediction of quality of intact banana using spectroscopy. Sci. Hortic. 2012, 135, 14-22. [CrossRef]

53. Adebayo, S.E.; Hashim, N.; Abdan, K.; Hanafi, M.; Mollazade, K. Prediction of quality attributes and ripeness classification of bananas using optical properties. Sci. Hortic. 2016, 212, 171-182. [CrossRef]

54. Rajkumar, P.; Wang, N.; EImasry, G.; Raghavan, G.S.V.; Gariepy, Y. Studies on banana fruit quality and maturity stages using hyperspectral imaging. J. Food Eng. 2012, 108, 194-200. [CrossRef]

55. El-Bendary, N.; El Hariri, E.; Hassanien, A.E.; Badr, A. Using machine learning techniques for evaluating tomato ripeness. Expert Syst. Appl. 2015, 42, 1892-1905. [CrossRef]

56. Batu, A. Determination of acceptable firmness and colour values of tomatoes. J. Food Eng. 2004, 61, 471-475. [CrossRef]

57. Saad, A.; Ibrahim, A.; El-Bialee, N. Internal quality assessment of tomato fruits using image color analysis. Agric. Eng. Int. CIGR J. 2016, 18, 339-352.

58. Gastélum-Barrios, A.; López-Bórquez, R.; Rico-García, E.; Toledano-Ayala, M.; Soto-Zarazúa, G. Tomato quality evaluation with image processing: A review. Afr. J. Agric. Res. 2011, 6, 3333-3339. [CrossRef]

59. Schouten, R.E.; Huijben, T.P.M.; Tijskens, L.M.M.; van Kooten, O. Modelling quality attributes of truss tomatoes: Linking colour and firmness maturity. Postharvest Biol. Technol. 2007, 45, 298-306. [CrossRef]

60. Clément, A.; Dorais, M.; Vernon, M. Nondestructive measurement of fresh tomato lycopene content and other physicochemical characteristics using visible NIR spectroscopy. J. Agric. Food Chem. 2008, 56, 9813-9818. [CrossRef] [PubMed]

61. Clément, A.; Dorais, M.; Vernon, M. Multivariate approach to the measurement of tomato maturity and gustatory attributes and their rapid assessment by vis-NIR spectroscopy. J. Agric. Food Chem. 2008, 56, 1538-1544. [CrossRef] [PubMed]

62. Hoffmann, A.M.; Noga, G.; Hunsche, M. Fluorescence indices for monitoring the ripening of tomatoes in pre- and postharvest phases. Sci. Hortic. 2015, 191, 74-81. [CrossRef]

63. Liu, C.; Liu, W.; Chen, W.; Yang, J.; Zheng, L. Feasibility in multispectral imaging for predicting the content of bioactive compounds in intact tomato fruit. Food Chem. 2015, 173, 482-488. [CrossRef] [PubMed]

64. Long, R.L.; Walsh, K.B. Limitations to the measurement of intact melon total soluble solids using near infrared spectroscopy. Aust. J. Agric. Res. 2006, 57, 403-410. [CrossRef] 
65. McGlone, V.A.; Fraser, D.G.; Jordan, R.B.; Künnemeyer, R. Internal quality assessment of mandarin fruit by vis/NIR spectroscopy. J. Near Infrared Spectrosc. 2003, 11, 323-332. [CrossRef]

66. Greensill, C.V.; Walsh, K.B. Calibration transfer between miniature photodiode array-based spectrometers in the near infrared assessment of mandarin soluble solids content. J. Near Infrared Spectrosc. 2002, 10, 27-36. [CrossRef]

67. Gómez, A.H.; He, Y.; Pereira, A.G. Non-destructive measurement of acidity, soluble solids and firmness of Satsuma mandarin using Vis/NIR-spectroscopy techniques. J. Food Eng. 2006, 77, 313-319. [CrossRef]

68. Guthrie, J.A.; Reid, D.J.; Walsh, K.B. Assessment of internal quality attributes of mandarin fruit. 2. NIR calibration model robustness. Aust. J. Agric. Res. 2005, 56, 417-426. [CrossRef]

69. Crisosto, C.H.; Crisosto, G.M.; Ritenour, M.A. Testing the reliability of skin color as an indicator of quality for early season "Brooks" (Prunus avium L.) cherry. Postharvest Biol. Technol. 2002, 24, 147-154. [CrossRef]

70. Lu, R. Predicting firmness and sugar content of sweet cherries using near-infrared diffuse reflectance spectroscopy. Trans. Am. Soc. Agric. Eng. 2001, 44, 1265-1271. [CrossRef]

71. Carlini, P.; Massantini, R.; Mencarelli, F. Vis-NIR measurement of soluble solids in cherry and apricot by PLS regression and wavelength selection. J. Agric. Food Chem. 2000, 48, 5236-5242. [CrossRef] [PubMed]

72. Sánchez, M.T.; De La Haba, M.J.; Benítez-López, M.; Fernández-Novales, J.; Garrido-Varo, A.; Pérez-Marín, D. Non-destructive characterization and quality control of intact strawberries based on NIR spectral data. J. Food Eng. 2012, 110, 102-108. [CrossRef]

73. Amodio, M.L.; Ceglie, F.; Chaudhry, M.M.A.; Piazzolla, F.; Colelli, G. Potential of NIR spectroscopy for predicting internal quality and discriminating among strawberry fruits from different production systems. Postharvest Biol. Technol. 2017, 125, 112-121. [CrossRef]

74. Liu, C.; Liu, W.; Lu, X.; Ma, F.; Chen, W.; Yang, J.; Zheng, L. Application of multispectral imaging to determine quality attributes and ripeness stage in strawberry fruit. PLOS ONE 2014, 9, e87818. [CrossRef] [PubMed]

75. ElMasry, G.; Wang, N.; ElSayed, A.; Ngadi, M. Hyperspectral imaging for nondestructive determination of some quality attributes for strawberry. J. Food Eng. 2007, 81, 98-107. [CrossRef]

76. Liu, M.; Fu, P.; Cheng, R. Non destructive estimation peach SSC and firmness by mutispectral reflectance imaging. N. Z. J. Agric. Res. 2007, 50, 601-608. [CrossRef]

77. Tallada, J.G.; Nagata, M.; Kobayashi, T. Non-destructive estimation of firmness of strawberries (Fragaria $\times$ ananassa Duch.) using NIR hyperspectral imaging. Environ. Control Biol. 2006, 44, 245-255. [CrossRef]

78. Camps, C.; Christen, D. Non-destructive assessment of apricot fruit quality by portable visible-near infrared spectroscopy. LWT Food Sci. Technol. 2009, 42, 1125-1131. [CrossRef]

79. Slaughter, D.C.; Crisosto, C.H. Nondestructive internal quality assessment of kiwifruit using near-infrared spectroscopy. Semin. Food Anal. 1998, 3, 131-140.

80. Lee, J.; Kim, S.; Seong, K.; Kim, C.; Um, Y.; Lee, S. Quality prediction of kiwifruit based on near infrared spectroscopy. Korean J. Hortic. Sci. Technol. 2012, 30, 709-717. [CrossRef]

81. McGlone, V.A.; Kawano, S. Firmness, dry-matter and soluble-solids assessment of postharvest kiwifruit by NIR spectroscopy. Postharvest Biol. Technol. 1998, 13, 131-141. [CrossRef]

82. Jannok, P.; Kamitani, Y.; Kawano, S. Development of a common calibration model for determining the Brix value of intact apple, pear and persimmon fruits by near infrared spectroscopy. J. Near Infrared Spectrosc. 2014, 22, 367-373. [CrossRef]

83. Wei, X.; Liu, F.; Qiu, Z.; Shao, Y.; He, Y. Ripeness classification of Astringent persimmon using hyperspectral imaging technique. Food Bioprocess Technol. 2014, 7, 1371-1380. [CrossRef]

84. Omar, A.F. Spectroscopic profiling of soluble solids content and acidity of intact grape, lime, and star fruit. Sens. Rev. 2013, 33, 238-245. [CrossRef]

85. Janik, L.J.; Cozzolino, D.; Dambergs, R.; Cynkar, W.; Gishen, M. The prediction of total anthocyanin concentration in red-grape homogenates using visible-near-infrared spectroscopy and artificial neural networks. Anal. Chim. Acta 2007, 594, 107-118. [CrossRef] [PubMed]

86. Agati, G.; D’Onofrio, C.; Ducci, E.; Cuzzola, A.; Remorini, D.; Tuccio, L.; Lazzini, F.; Mattii, G. Potential of a multiparametric optical sensor for determining in situ the maturity components of red and white Vitis vinifera wine grapes. J. Agric. Food Chem. 2013, 61, 12211-12218. [CrossRef] [PubMed] 
87. Lenk, S.; Buschmann, C.; Pfündel, E.E. In vivo assessing flavonols in white grape berries (Vitis vinifera L. cv. Pinot Blanc) of different degrees of ripeness using chlorophyll fluorescence imaging. Funct. Plant Biol. 2007, 34, 1092-1104. [CrossRef]

88. Baiano, A.; Terracone, C.; Peri, G.; Romaniello, R. Application of hyperspectral imaging for prediction of physico-chemical and sensory characteristics of table grapes. Comput. Electron. Agric. 2012, 87, 142-151. [CrossRef]

89. Abu Bakar, B.H.; Ishak, A.J.; Shamsuddin, R.; Wan Hassan, W.Z. Ripeness level classification for pineapple using RGB and HSI colour maps. J. Theor. Appl. Inf. Technol. 2013, 57, 587-593.

90. Guthrie, J.; Walsh, K. Non-invasive assessment of pineapple and mango fruit quality using near infra-red spectroscopy. Aust. J. Exp. Agric. 1997, 37, 253-263. [CrossRef]

91. Chia, K.S.; Abdul Rahim, H.; Abdul Rahim, R. Prediction of soluble solids content of pineapple via non-invasive low cost visible and shortwave near infrared spectroscopy and artificial neural network. Biosyst. Eng. 2012, 113, 158-165. [CrossRef]

92. Infante, R.; Contador, L.; Rubio, P.; Mesa, K.; Meneses, C. Non-destructive monitoring of flesh softening in the black-skinned Japanese plums "Angeleno" and "Autumn beaut" on-tree and postharvest. Postharvest Biol. Technol. 2011, 61, 35-40. [CrossRef]

93. Paz, P.; Sánchez, M.T.; Pérez-Marín, D.; Guerrero, J.E.; Garrido-Varo, A. Nondestructive determination of total soluble solid content and firmness in plums using near-infrared reflectance spectroscopy. J. Agric. Food Chem. 2008, 56, 2565-2570. [CrossRef] [PubMed]

94. Mendoza, F.; Aguilera, J.M. Application of Image Analysis for Classification of Ripening Bananas. Food Eng. Phys. Prop. 2004, 69, 478-487. [CrossRef]

95. Olmo, M.; Nadas, A.; García, J.M. Nondestructive Methods to Evaluate Maturity Level of Oranges. Sens. Nutr. Qual. Food Nondestruct. 1998, 65, 365-369. [CrossRef]

96. Shewfelt, R.L.; Thai, C.N.; Davis, J.W. Prediction of changes in color of tomatoes during ripening at different constant temperatures. J. Food Sci. 1988, 53, 1433. [CrossRef]

97. Mercado-Silva, E.; Benito-Bautista, P.; De los Angeles García-Velasco, M. Fruit development, harvest index and ripening changes of guavas produced in central Mexico. Postharvest Biol. Technol. 1998, 13, 143-150. [CrossRef]

98. Shinya, P.; Contador, L.; Predieri, S.; Rubio, P.; Infante, R. Peach ripening: Segregation at harvest and postharvest flesh softening. Postharvest Biol. Technol. 2013, 86, 472-478. [CrossRef]

99. Raut, K.; Bora, V. Assessment of fruit maturity using digital image processing. Int. J. Sci. Technol. Eng. 2016, $3,273-279$.

100. Taghadomi-Saberi, S.; Omid, M.; Emam-Djomeh, Z.; Faraji-Mahyari, K.H. Determination of cherry color parameters during ripening by artificial neural network assisted image processing technique. J. Agric. Sci. Technol. 2015, 17, 589-600.

101. Hobson, G.E.; Adams, P.; Dixon, T.J. Assessing the colour of tomato fruit during ripening. J. Sci. Food Agric. 1983, 34, 286-292. [CrossRef]

102. Camelo, A.F.L.; Gómez, P.A. Comparison of color indexes for tomato ripening. Hortic. Bras. 2004, 22, $534-537$. [CrossRef]

103. Wu, D.; Sun, D.W. Colour measurements by computer vision for food quality control-A review. Trends Food Sci. Technol. 2013, 29, 5-20. [CrossRef]

104. Tijskens, L.M.M.; Evelo, R.G. Modelling colour of tomatoes during postharvest storage. Postharvest Biol. Technol. 1994, 4, 85-98. [CrossRef]

105. Arias, R.; Lee, T.-C.; Logendra, L.; Janes, H. Correlation of lycopene measured by HPLC with the L*, $a^{*}, b^{*}$ color readings of a hydroponic tomato and the relationship of maturity with color and lycopene content. J. Agric. Food Chem. 2000, 48, 1697-1702. [CrossRef] [PubMed]

106. Brandt, S.; Pék, Z.; Barna, É.; Lugasi, A.; Helyes, L. Lycopene content and colour of ripening tomatoes as affected by environmental conditions. J. Sci. Food Agric. 2006, 86, 568-572. [CrossRef]

107. D'Souza, M.C.; Singha, S.; Ingle, M. Lycopene concentration of tomato fruit can be estimated from chromaticity values. HortScience 1992, 27, 465-466.

108. Jiménez-Cuesta, M.; Cuquerella, J.; Martinez-Javaga, J.M. Determination of a color index for citrus fruit degreening. In Proceedings of the International Society of Citriculture, Tokyo, Japan, 15-23 August 1978. 
109. Yam, K.L.; Papadakis, S.E. A simple digital imaging method for measuring and analyzing color of food surfaces. J. Food Eng. 2004, 61, 137-142. [CrossRef]

110. León, K.; Mery, D.; Pedreschi, F.; León, J. Color measurement in $\mathrm{L}^{*}, \mathrm{a}^{*}, \mathrm{~b}^{*}$ units from RGB digital images. Food Res. Int. 2006, 39, 1084-1091. [CrossRef]

111. Klir, G.; Yuan, B. Fuzzy Sets and Fuzzy Logic; Prentice hall: Upper Saddle River, NJ, USA, 1995; Volume 4.

112. Mansor, A.R.; Othman, M.; Ahmad, K.A.; Nazari, M.; Bakar, A.; Razak, T.R. Fuzzy RGB colour sensor model for mango ripening index. In Proceedings of the 2013 IEEE Symposium on Humanities, Science \& Engineering Research, Penang, Malaysia, 23-26 June 2013; pp. 118-123.

113. Goel, N.; Sehgal, P. Fuzzy classification of pre-harvest tomatoes for ripeness estimation-An approach based on automatic rule learning using decision tree. Appl. Soft Comput. J. 2015, 36, 45-56. [CrossRef]

114. Hartigan, J.A.; Wong, M.A. Algorithm AS 136: A k-means clustering algorithm. J. R. Stat. Soc. Ser. C (Appl. Stat.) 1979, 28, 100-108. [CrossRef]

115. Lesot, M.-J.; Kruse, R. Gustafson-Kessel-like clustering algorithm based on typicality degrees. In Uncertainty and Intelligent Information Systems; World Scientific: Hackensack, NJ, USA, 2006, 117-130.

116. Dadwal, M.; Banga, V.K. Color image segmentation for fruit ripeness detection: A review. In Proceedings of the 2nd International Conference on Electrical, Electronics and Civil Engineering (ICEECE'2012), Singapore, 28-29 April 2012; pp. 190-193.

117. Niño-Medina, G.; Rivera-Castro, J.C.; Vidales-Contreras, J.A.; Rodriguez-Fuentes, H.; Luna-Maldonado, A.I. Physicochemical parameters for obtaining prediction models in the postharvest quality of tomatoes (Solanum Lycopersicum L.). Trans. Mach. Learn. 2013, 6, 54-66.

118. Takahashi, N.; Maki, H.; Nishina, H.; Takayama, K. Evaluation of tomato fruit color change with different maturity stages and storage temperatures using image analysis. IFAC Proc. 2013, 46, 147-149. [CrossRef]

119. Yanai, H.; Mayekawa, S. Review of linear algebra and linear models by R.B. Bapat. Linear Algebra Appl. 1994, 207, 273-277. [CrossRef]

120. Jain, A.K.; Mao, J. Artificial neural network: A tutorial. Communications 1996, 29, 31-44. [CrossRef]

121. Hartmann, A.; Czauderna, T.; Hoffmann, R.; Stein, N.; Schreiber, F. HTPheno: An image analysis pipeline for high-throughput plant phenotyping. BMC Bioinform. 2011, 12, 148. [CrossRef] [PubMed]

122. Sural, S.; Qian, G.; Pramanik, S. Segmentation and histogram generation using the HSV color space for image retrival. In Proceedings of the 2002 International Conference on Image Processing, New York, NY, USA, 22-25 September 2002; Volume 2.

123. Ukirade, N.S. Color grading system for evaluating tomato maturity. Int. J. Res. Manag. Sci. Technol. 2014, 2, $41-45$.

124. Duda, R.O.; Hart, P.E.; Stork, D.G. Pattern Classification; John Wiley \& Sons: Hoboken, NJ, USA, 2012; ISBN 111858600X.

125. Li, H.; Lee, W.S.; Wang, K. Identifying blueberry fruit of different growth stages using natural outdoor color images. Comput. Electron. Agric. 2014, 106, 91-101. [CrossRef]

126. Tarkosova, J.; Copikova, J. Determination of carbohydrate content in bananas during ripening and storage by near infrared spectroscopy. J. Near Infrared Spectrosc. 2000, 8, 21-26. [CrossRef]

127. Makky, M.; Soni, P. In situ quality assessment of intact oil palm fresh fruit bunches using rapid portable non-contact and non-destructive approach. J. Food Eng. 2014, 120, 248-259. [CrossRef]

128. Lleó, L.; Roger, J.M.; Herrero-Langreo, A.; Diezma-Iglesias, B.; Barreiro, P. Comparison of multispectral indexes extracted from hyperspectral images for the assessment of fruit ripening. J. Food Eng. 2011, 104, 612-620. [CrossRef]

129. Ruiz-Altisent, M.; Lleó, L.; Riquelme, F. Instrumental quality assessment of peaches: Fusion of optical and mechanical parameters. J. Food Eng. 2006, 74, 490-499. [CrossRef]

130. Lurie, S.; Friedman, H.; Weksler, A.; Dagar, A.; Eccher Zerbini, P. Maturity assessment at harvest and prediction of softening in an early and late season melting peach. Postharvest Biol. Technol. 2013, 76, 10-16. [CrossRef]

131. Costa, G.; Noferini, M.; Fiori, G.; Ziosi, V.; Berthod, N.; Rossier, J. Establishment of the optimal harvest time in apricot ('Orangered' and 'Bergarouge') by means of a new index based on vis spectroscopy. Acta Hortic. 2010, 862, 533-539. [CrossRef]

132. Costa, G.; Noferini, M.; Fiori, G.; Torrigiani, P. Use of vis/nir spectroscopy to assess fruit ripening stage and improve management in post-harvest chain. Fresh Prod. 2009, 3, 35-41. 
133. Bonora, E.; Noferini, M.; Stefanelli, D.; Costa, G. A new simple modeling approach for the early prediction of harvest date and yield in nectarines. Sci. Hortic. 2014, 172, 1-9. [CrossRef]

134. Helland, I. Partial least squares regression. In Encyclopedia of Statistical Sciences; John Wiley \& Sons: Hoboken, NJ, USA, 2006.

135. Mahesh, S.; Jayas, D.S.; Paliwal, J.; White, N.D.G. Comparison of partial least squares regression (PLSR) and principal components regression (PCR) methods for protein and hardness predictions using the near-infrared (NIR) hyperspectral images of bulk samples of Canadian wheat. Food Bioprocess Technol. 2014, 8, 31-40. [CrossRef]

136. Rinnan, Å; Berg, F.V.D.; Engelsen, S.B. Review of the most common pre-processing techniques for near-infrared spectra. TrAC Trends Anal. Chem. 2009, 28, 1201-1222. [CrossRef]

137. Mollazade, K.; Omid, M.; Tab, F.A.; Mohtasebi, S.S. Principles and applications of light backscattering imaging in quality evaluation of agro-food products: A review. Food Bioprocess Technol. 2012, 5, 1465-1485. [CrossRef]

138. Herrera, J.; Guesalaga, A.; Agosin, E. Shortwave near infrared spectroscopy for non-destructive determination of maturity of wine grapes. Meas. Sci. Technol. 2003, 14, 689-697. [CrossRef]

139. Guo, Z.; Huang, W.; Chen, L.; Wang, X.; Peng, Y. Nondestructive evaluation of soluble solid content in strawberry by near infrared spectroscopy. In Proceedings of the Third International Conference on Photonics and Image in Agriculture Engineering (PIAGENG 2013), Sanya, China, 4 March 2013. [CrossRef]

140. Gorry, P.A. General least-squares smoothing and differentiation by the convolution (Savitzky-Golay) method. Anal. Chem. 1990, 62, 570-573. [CrossRef]

141. Nicolai, B.M.; Beullens, K.; Bobelyn, E.; Peirs, A.; Saeys, W.; Theron, K.I.; Lammertyn, J. Nondestructive measurement of fruit and vegetable quality by means of NIR spectroscopy: A review. Postharvest Biol. Technol. 2007, 46, 99-118. [CrossRef]

142. Marques, E.J.N.; De Freitas, S.T.; Pimentel, M.F.; Pasquini, C. Rapid and non-destructive determination of quality parameters in the "Tommy Atkins" mango using a novel handheld near infrared spectrometer. Food Chem. 2016, 197, 1207-1214. [CrossRef] [PubMed]

143. Torres, I.; Pérez-Marín, D.; De la Haba, M.J.; Sánchez, M.T. Fast and accurate quality assessment of Raf tomatoes using NIRS technology. Postharvest Biol. Technol. 2015, 107, 9-15. [CrossRef]

144. He, Y.; Zhang, Y.; Pereira, A.G.; Gómez, A.H.; Wang, J. Nondestructive determination of tomato fruit quality characteristics using vis/nir spectroscopy technique. Int. J. Inf. Technol. 2005, 11, 97-108.

145. Saranwong, S.; Sornsrivichai, J.; Kawano, S. Prediction of ripe-stage eating quality of mango fruit from its harvest quality measured nondestructively by near infrared spectroscopy. Postharvest Biol. Technol. 2004, 31, 137-145. [CrossRef]

146. Ma, G.; Fu, X.; Zhou, Y.; Ying, Y.; Xu, H.; Xie, L.; Lin, T. Nondestructive sugar content determination of peaches by using near infrared spectroscopy technique. Spectrosc. Spectr. Anal. 2007, 27, 907-910.

147. Dhanoa, M.; Lister, S.; Sanderson, R.; Barnes, R. The link between multiplicative scatter correction (MSC) and standard normal variate (SNV) transformations of NIR spectra. J. Near Infrared Spectrosc. 1994, 2, $43-47$. [CrossRef]

148. Nishizawa, T.; Mori, Y.; Fukushima, S.; Natsuga, M.; Maruyama, Y. Non-destructive analysis of soluble sugar components in strawberry fruits using near-infrared spectroscopy. J. Jpn. Soc. Food Sci. Technol. 2009, 56, 229-235. [CrossRef]

149. Peiris, K.H.S.; Dull, G.G.; Leffler, R.G.; Kays, S.J. Near-infrared spectrometric method for nondestructive determination of soluble solids content of peaches. J. Am. Soc. Hortic. Sci. 1998, 123, 898-905.

150. Saranwong, S.; Sornsrivichai, J.; Kawano, S. Improvement of PLS calibration for Brix value and dry matter of mango using information from MLR calibration. J. Near Infrared Spectrosc. 2001, 9, 287-295. [CrossRef]

151. Kawano, S.; Watanabe, H.; Iwamoto, M. Determination of sugar content in intact peaches by near infrared spectroscopy with fiber optics in interactance mode. J. Jpn. Soc. Hortic. Sci. 1992, 61, 445-451. [CrossRef]

152. Jiang, M.; Lu, H.; Ying, Y.; Xu, H. Design and validation of software for real-time soluble solids content evaluation of peach by near infrared spectroscopy. Opt. Natl. Resour. Agric. Foods 2006, 6381, 638118. [CrossRef]

153. Guthrie, J.; Wedding, B.; Walsh, K. Robustness of NIR calibrations for soluble solids in intact melon and pineapple. J. Near Infrared Spectrosc. 1998, 6, 259-265. [CrossRef] 
154. Ouyang, A.G. Partial least squares regression variable screening studies on apple soluble solids nir spectral detection. Spectrosc. Spectr. Anal. 2012, 32, 2680-2684.

155. Jha, S.N.; Narsaiah, K.; Jaiswal, P.; Bhardwaj, R.; Gupta, M.; Kumar, R.; Sharma, R. Nondestructive prediction of maturity of mango using near infrared spectroscopy. J. Food Eng. 2014, 124, 152-157. [CrossRef]

156. Park, B.; Abbott, J.A.; Lee, K.J.; Choi, C.H.; Choi, K.H. Near-infrared diffuse reflectance for quantitative and qualitative measurement of soluble solids and firmness of Delicious and Gala apples. Trans. ASAE 2003, 46, 1721-1731. [CrossRef]

157. Gracia, A.; León, L. Non-destructive assessment of olive fruit ripening by portable near infrared spectroscopy. Grasas Y Aceites 2011, 62, 268-274. [CrossRef]

158. Herold, B.; Truppel, I.; Zude, M.; Geyer, M. Spectral measurements on 'Elstar' apples during fruit development on the tree. Biosyst. Eng. 2005, 91, 173-182. [CrossRef]

159. Royer, C.A. Fluorescence spectroscopy. Methods Mol. Biol. 1995, 40, 65-89. [CrossRef] [PubMed]

160. Song, J.; Deng, W.; Beaudry, R.M.; Armstrong, P.R. Changes in chlorophyll fluorescence of apple fruit during maturation, ripening, and senescence. HortScience 1997, 32, 891-896.

161. Bron, I.U.; Ribeiro, R.V.; Azzolini, M.; Jacomino, A.P.; Machado, E.C. Chlorophyll fluorescence as a tool to evaluate the ripening of "Golden" papaya fruit. Postharvest Biol. Technol. 2004, 33, 163-173. [CrossRef]

162. Morales, F.; Cerovic, Z.G.; Moya, I. Time-resolved blue-green fluorescence of sugar beet (Beta vulgaris L.) leaves. Spectroscopic evidence for the presence of ferulic acid as the main fluorophore of the epidermis. Biochim. Biophys. Acta Bioenergy 1996, 1273, 251-262. [CrossRef]

163. Hazir, M.H.M.; Shariff, A.R.M.; Amiruddin, M.D.; Ramli, A.R.; Iqbal Saripan, M. Oil palm bunch ripeness classification using fluorescence technique. J. Food Eng. 2012, 113, 534-540. [CrossRef]

164. ElMasry, G.M.; Nakauchi, S. Image analysis operations applied to hyperspectral images for non-invasive sensing of food Quality-A comprehensive review. Biosyst. Eng. 2016, 142, 53-82. [CrossRef]

165. Mahesh, S.; Jayas, D.S.; Paliwal, J.; White, N.D.G. Hyperspectral imaging to classify and monitor quality of agricultural materials. J. Stored Prod. Res. 2015, 61, 17-26. [CrossRef]

166. Bauriegel, E.; Giebel, A.; Geyer, M.; Schmidt, U.; Herppich, W.B. Early detection of Fusarium infection in wheat using hyper-spectral imaging. Comput. Electron. Agric. 2011, 75, 304-312. [CrossRef]

167. Zhao, Y.; Gong, L.; Huang, Y.; Liu, C. Robust tomato recognition for robotic harvesting using feature images fusion. Sensors 2016, 16, 173. [CrossRef] [PubMed]

168. Honkavaara, E.; Kaivosoja, J.; Mäkynen, J.; Pellikka, I.; Pesonen, L.; Saari, H.; Salo, H.; Hakala, T.; Marklelin, L.; Rosnell, T. Hyperspectral reflectance signatures and point clouds for precision agriculture by light weight uav imaging system. ISPRS Ann. Photogramm. Remote Sens. Spat. Inf. Sci. 2012, I-7, 353-358. [CrossRef]

169. Centner, V.; Massart, D.-L.; de Noord, O.E.; de Jong, S.; Vandeginste, B.M.; Sterna, C. Elimination of uninformative variables for multivariate calibration. Anal. Chem. 1996, 68, 3851-3858. [CrossRef] [PubMed]

170. Zhu, Q.; Huang, M.; Zhao, X.; Wang, S. Wavelength selection of hyperspectral scattering image using new semi-supervised affinity propagation for prediction of firmness and soluble solid content in apples. Food Anal. Methods 2013, 6, 334-342. [CrossRef]

171. Wang, S.; Huang, M.; Zhu, Q. Model fusion for prediction of apple firmness using hyperspectral scattering image. Comput. Electron. Agric. 2012, 80,1-7. [CrossRef]

172. Leiva-Valenzuela, G.A.; Lu, R.; Aguilera, J.M. Assessment of internal quality of blueberries using hyperspectral transmittance and reflectance images with whole spectra or selected wavelengths. Innov. Food Sci. Emerg. Technol. 2014, 115, 91-98. [CrossRef]

173. Araújo, M.C.U.; Saldanha, T.C.B.; Galvão, R.K.H.; Yoneyama, T.; Chame, H.C.; Visani, V. The successive projections algorithm for variable selection in spectroscopic multicomponent analysis. Chemom. Intell. Lab. Syst. 2001, 57, 65-73. [CrossRef]

174. Peng, Y.; Lu, R. An LCTF-based multispectral imaging system for estimation of apple fruit firmness: Part I. Acquisition and characterization of scattering images. Trans. ASABE 2006, 49, 259-267. [CrossRef]

175. Saeed, O.M.B.; Sankaran, S.; Shariff, A.R.M.; Shafri, H.Z.M.; Ehsani, R.; Alfatni, M.S.; Hazir, M.H.M. Classification of oil palm fresh fruit bunches based on their maturity using portable four-band sensor system. Comput. Electron. Agric. 2012, 82, 55-60. [CrossRef]

176. Yang, H. Remote sensing technique for predicting harvest time of tomatoes. Procedia Environ. Sci. 2011, 10, 666-671. [CrossRef] 
177. Peirs, A.; Lammertyn, J.; Ooms, K.; Nicolaï, B.M. Prediction of the optimal picking date of different apple cultivars by means of VIS/NIR-spectroscopy. Postharvest Biol. Technol. 2001, 21, 189-199. [CrossRef]

178. Teng, L.; Cheng, Z.; Chen, X.; Lai, L. Study on simulation models of tomato fruit quality related to cultivation environmental factors. Acta Ecol. Sin. 2012, 32, 111-116. [CrossRef]

179. Loomis, R.S.; Williams, W.A. Maximum crop productivity: An extimate. Crop Sci. 1963, 3, 67-72. [CrossRef]

180. Jones, C.A.; Kiniry, J.R. CERES-Maize: A Simulation Model of Maize Growth and Development; Texas A\&M University Press: College Station, TX, USA, 1986.

181. Whisler, F.D.; Acock, B.; Baker, D.N.; Fye, R.E.; Hodges, H.F.; Lambert, J.R.; Lemmon, H.E.; McKinion, J.M.; Reddy, V.R. Crop simulation models in agronomic systems. Adv. Agron. 1986, 40, 141-208.

182. Yang, H.; Dobermann, A.; Cassman, K.G.; Walters, D.T. Features, applications, and limitations of the hybrid-maize simulation model. Agron. J. 2006, 98, 737-748. [CrossRef]

183. Jones, J.W.; Dayan, E.; Allen, L.H.; Keulen, H.V.; Challa, H. A dynamic tomato growth and yield model (Tomgro). Trans. ASAE 1991, 34, 663-672. [CrossRef]

184. Gijzen, H.; Heuvelink, E.; Challa, H.; Dayan, E.; Marcelis, L.F.M.; Cohen, S.; Fuchs, M. Hortisim: A model for greenhouse crops and greenhouse climate. Acta Hortic. 1998, 456, 441-450. [CrossRef]

185. Qiu, Q.; Shi, K.; Qiao, X.J.; Jiang, K. Determining the dominant environmental parameters for greenhouse tomato seedling growth modeling using canonical correlation analysis. IFAC-PapersOnLine 2016, 49, 387-391. [CrossRef]

186. Tomana, T.; Utsunomiya, N.; Kataoka, I. The effect of environmental temperatures on fruit ripening on the tree II. The effect of temperatures around whole vines and clusters on the coloration of "Kyoho" grapes. J. Jpn. Soc. Hortic. Sci. 1979, 48, 261-266. [CrossRef]

187. Yamada, H.; Ohmura, H.; Arai, C.; Terui, M. Effect of preharvest fruit temperature on ripening, sugars, and watercore occurrence in apples. J. Am. Soc. Hortic. Sci. 1994, 119, 1208-1214.

188. Medlicott, A.P.; Reynolds, S.B.; Thompson, A.K. Effects of temperature on the ripening of mango. J. Sci. Food Agric. 1986, 37, 469-474. [CrossRef]

189. Nanos, G.D.; Lazaridou, M.; Tsoukidou, M.; Sfakiotakis, E.M. Effects of temperature and propylene on apricot ripening. Int. Soc. Hortic. Sci. 1997, 488. [CrossRef]

190. Cordenunsi, B.R.; Genovese, M.I.; Oliveira Do Nascimento, J.R.; Aymoto Hassimotto, N.M.; José Dos Santos, R.; Lajolo, F.M. Effects of temperature on the chemical composition and antioxidant activity of three strawberry cultivars. Food Chem. 2005, 91, 113-121. [CrossRef]

191. Kawano, S.; Abe, H. Development of a calibration equation with temperature compensation for determining the Brix value in intact peaches. J. Near Infrared Spectrosc. 1995, 3, 211-218. [CrossRef]

192. Gustafsson, J.; Cederberg, C.; Sonesson, U.; Emanuelsson, A. The Methodology of the FAO Study: Global Food Losses and Food Waste-Extent, Causes and Prevention-FAO, 2011; The Swedish Institute for Food and Biotechnology: Stockholm, Sweden, 2013. 